PETR KOZEL

\title{
CONTRIBUTION TO SOME MILITARY-ECOLOGICAL ASPECTS OF MILITARY TRAINING AREAS
}

P. Kozel: Contribution to Some Military-ecological Aspects of Military Training Areas. - Geografie - Sborník CGS, 103, 3, pp. 352 - 355 (1998). - The article deals with the importance, past, present and future of military training areas and with internal military measures regulating nature and land protection in these areas.

KEY WORDS: military training areas - landscape protection - environmental program.

\section{Introduction}

Military lands (ML) are exceptional territorial administrative units established by the Act No 169/1949 about military lands in reading of ensuing regulations. Military lands, as independent territorial administrative units, are administrated by the land authorities headed by the land administrator.

Military training areas (MTA) are specifically delimited parts of national territory intended for field military training and mainly established within military lands. Their total area covers nearly $1.6 \%$ of the total state area and it is used, besides the military purposes, also for forestry and agriculture benefits.

The usage of military land territories is controlled by three subjects, ensuring in fact the needs of the Army of the Czech Republic. State administration, including environment protection, is managed by the Military land bureau, military activities are controlled by the MTA commandment and economic usage is managed by different branches of the state organization Military forests and farms. The three above-mentioned subjects co-operate.

Military lands are thus not only territories serviceable to military training, but at the same time territorial units with irreplaceable natural, landscape, ecological and economic values. These values result from natural landscape building processes and human activities completing together the unique secondary landscape structure (Kozel 1988).

\section{Recent past of military lands}

Until 1989, the Czechoslovak army used in the area of twelve military lands fourteen military training areas, eight of them on the territory of the Czech Republic and six on the territory of the Slovak Republic with total area of 264857 ha (Komár 1993). In the Czech Republic, there were Boletice, Dobrá Voda, Hradiště, Libavá and Mladá military lands with military training areas of the same name and Brdy, Dobrá Voda and Ralsko MLs with respectively Jince, Dědice and Mimoň MTAs. 
After the changes in the political situation in 1989, differently motivated social pressures on the territories of MLs, and their respective MTAs, increased. Many realistic exigencies aimed at optimizing their use and at eliminating damages mainly caused by the Soviet army, were accompanied by pressures caused by the considerable changes of their limits or even to the abolition of military lands completely. MLs and MTAs were regarded as residues of the past, useless anachronisms, etc. Besides showing political and ecological naiveté, personal and group interest were often placed before common needs. In the first case, it was due to the fact that problems connected with the state of the environment resulting from military activities were in the past often kept secret, and in the second case it was due to the desire to make use of military lands or of their parts, for business or recreation activities that were often camouflaged by ecological pretexts. This has also proved the case during the following eight years and mainly after the division of Czechoslovakia, when the existence of some military lands and military training areas has shown itself indispensable for military and political reasons, as well as for direct and indirect nature and landscape protection (Kozel 1995).

After considering all the available facts and in compliance with the new military doctrine, it was decided to put an end, from the 31th of December 1992, to military usage of three military lands in the Czech Republic (Dobrá Voda, Mladá and Ralsko) and of their respective military training areas. This decision did not include some plots, buildings and equipments necessary to the defence of state. After the transfer of these military lands to civil administration, the first one became the core of the Sumava National Park, and revitalization has been prepared in the other two. In the past, both military lands were almost exclusively used by Soviet troops and for that reason the state of their territory was much worse than in the other MLs. In this connection, many political, socio-economic and landscape ecological activities have been initiated in order to find a new utilization for them, especially in the case of the Ralsko ML. The participation of both Czech military and civil specialists in the pilot study of the NATO Committee for the development of modern society "Environmental Aspects of Reusing Former Military Lands" resulted in the elaboration of projects proposing use of this universally attractive and valuable territory (Poštolka et al. 1997).

\section{Existing MLs (MTAs) and nature and landscape protection on their territory}

At present, there are five military lands on the territory of the Czech Republic. A survey of their areas, names of respective MTAs and seats of branches of the Military forests and farms (MFF - in the case of the Brezina ML only Military forests) are given in the table 1.

In all the above mentioned territories, a great deal of attention is paid to nature and landscape protection. Besides the general duties of all members of the Army of the Czech Republic concerning environmental protection, given by many internal normative acts (INA), several special INAs were elaborated by the Ministry of Defence to minimize, eliminate and especially to prevent ecological damage due to military training. The most detailed of them are the Methodological instructions of the Head of Environment Department of the 
Table1 - Military lands and MTAs in the Czech Republic

\begin{tabular}{|l|l|l|c|}
\hline ML & MTA & MFF & Total area (ha) \\
\hline Brdy & Jince & Hořovice & 26.034 \\
Boletice & Boletice & Horní Planá & 21.949 \\
Hradiště & Hradiště & Velichov & 33.162 \\
Libavá & Libavá & Lipník nad Bečvou & 32.580 \\
Březina & Dědice & Plumlov & 15.818 \\
\hline Total & & & 129.543 \\
\hline
\end{tabular}

Explanations: ML - Military lands; MTA - Military training areas; MFF - Military forests and farms.

Ministry of Defence in favour of general nature and landscape protection and specific plant protection on territories serving state defence purposes from the year 1996 (Komár 1996a), and the Methodological instruction of the Head of Environment Department of the Ministry of Defence concerning duties of selected functionaries in implementing environment protection principles on the territory of military lands from the same year (Komár 1996b).

The first document consequently deals with the application of the $\S 90$, paragraph 2, Act No 114/1992 and obliges the military administration staff to observe general principles of nature protection both for reasons of general interest and to increase the prestige of the military administration.

The second, more comprehensive document, determines the rights and duties of individual functionaries in implementation of environment protection principles on the territory of military lands. It concerns mainly military land administrators, military training region commanders, commanders of training troops during training, territorial ecologists and union ecologists. Especially detailed is Chapter D dealing with duties of commanders during the training. This part of Instruction covers the majority of possible cases of deterioration or damaging of nature and the environment and gives advice on how to prevent them and how to eliminate possible damages.

It is necessary to state that thanks to the effective co-operation of all the above-mentioned functionaries, the given tasks have mostly been successfully realized. Increasing pressures on usage of the territories of military lands, uncertainties about their future number and above all the state of infrastructure on their territory are factors that in perspective do not contribute to balancing the intensity of military usage, economic activities and the observation of principles of nature and landscape protection. The above-mentioned facts must be considered when establishing the future number and areas of military lands. The territories, on which the military training is practised, represent only part of the total area of military lands. Because of ensured training needs, the weapon systems used, security of persons and perspectives of their usage, the existing area of MLs is indispensable. The opening of certain parts of MLs to the general public after 1990 proved itself, following numerous previous warnings (Kozel 1990, 1995), unsuitable. Some visitors do not respect legal regulations about the access to military areas and may thus affect not only the intensity and smooth running of military training, but they may also cause damage to stationary equipment by theft, setting fires, etc. The possibility of injury or mortal danger by unexploded munitions is not negligible. The use of farming and forest areas is 
also complicated, and valuable communities are damaged. Ecological damage which may occur during military training is added to by further quite unnecessary damage.

\section{Future of military lands}

Recently, there have been increased pressures on the intensification of usage of existing MLs (MTAs) and on modernization, eventual building of new equipment necessary to ensure the mobilization needs of the Army of the Czech Republic, realization of targets in the area of military preparedness of state, accomplishment of training targets peace time, ensuring of training of non-military armed units and realization of special research and development aims. These pressures are also due to the fact that after the division of Czechoslovakia, some important training equipment has remained on the territory of the Slovak Republic and for that reason, it is necessary to build within the existing military lands new equipment. In addition, increased demands on ML territories and MTA equipment in connection with the entry of the Czech Republic to NATO are not negligible. The Czech government will decide after the approval of the "Conception of development of the department of Ministry of Defence" on the number of military lands, and respective military training areas (Ministerstvo obrany 1996).

\section{References:}

KOMÁR, A. (1993): Vojenský újezd Hradiště. Sborník ČGS, 98, No. 2, NČGS, Praha, pp. 7586.

KOMÁR, A. (1996a): Metodický pokyn vedoucího oddělení životního prostředí k obecné ochraně př́rody a krajiny a zvláštní ochraně rostlin na územích sloužících zájmům obrany státu. MO ČR, Praha, 2 p.

KOMÁR, A. (1996b): Metodický pokyn vedoucího oddělení životního prostředí k povinnostem vybraných funkcionárù Armády ČR př̀i plnění zásad ochrany životního prostředí na území vojenských újezdů. MO ČR, Praha, $7 \mathrm{p}$.

KOZEL, P. (1990): Doporučení $\mathrm{k}$ dalšímu využívání vojenského výcvikového prostoru Libavá. VLS, Lipník nad Bečvou, without page numbers.

KOZEL, P. (1988): Př́čciny změn produkčního potenciálu krajiny. AUPO, Fac. Rer. Nat., Biologica 93, XXVIII, pp 47-58.

KOZEL, P. (1995): Krajinně ekologická hlediska dalšího využívání vojenského výcvikového prostoru Libavá. Sborník referátů 3. celoarmádní konference EROP`95, sekce B. MO ČR, VVŠ PV Vyškov, pp. 31-36.

KOZEL, P.(1997): Ochrana přírody a krajiny ve vojenských újezdech. Sborník referátů Mezinárodní konference CATE ${ }^{\circ} 97,6$. sekce. VA Brno, pp. 79-82.

MINISTERSTVO OBRANY (1996): Záměr koncepce využivání vojenských újezdů a vojenských výcvikových prostorů do roku 2015. Praha, without page numbers.

POŠTOLKA, V. et al. (1997): Conversion/Reuse of the Former Military Traing Area Ralsko (Czech Republic). Technical University of Liberec \& Environmental Faculty of Ústí nad Labem, without page numbers.

(The author is with Ministry of Defence of the Czech Republic, Dobrovského 6, 77111 Olomouc.)

Arrived at the editor's office on April 21, 1997

Recommended for publication by Václav Poštolka and Zbyněk Ryšlavý 